\title{
Впровадження інформаційних систем обліку
}

\begin{abstract}
Мета статmі - визначити інформаційні системи обліку як елемент управління інформаційними ресурсами підприємства, порівняти критерії інформаційного наповнення регламентованої (фінансової) та управлінської звітності для формування інформаційного ресурсу підприємства.

Методика дослідження. Використано загальні й спеціальні методи наукового пізнання: системний підхід і системний аналіз (при визначенні сутності та основних елементів оцінки інформаційних потоків); історично-логічний метод (при дослідженні становлення, розвитку і розробки теоретичних та методологічних положень формування і запровадження інформаційних систем обліку); аналізу і синтезу (при розробці пропозицій щодо запровадження інформаційних систем обліку у практичній діяльності підприємства); монографічний (при оцінюванні результатів адаптації працівників підприємства, які повинні відповідати за впровадження платформи).

Результати дослідження. Доведено вагоме значення отриманих теоретичних і практичних розробок щодо формування та використання інформаційних систем обліку як основи формування інформаційного ресурсу підприємства для розвитку теорії обліку та впровадження їі положень у практичну діяльність суб'єктів господарювання. Викладено ряд практичних ситуацій, які можуть супроводжувати впровадження інформаційних систем обліку для інформаційного забезпечення ефективного управління.

Елементи наукової новизни. Узагальнено можливості вибору інформаційної платформи, на якій будуть проводитися збір, обробка та передача інформації з метою здійснення прийняття управлінських рішень.

Практична значущість. Обгрунтовано необхідність запровадження інформаційних систем обліку на підприємстві з передбаченням ряду методичних заходів щодо поділу інформації залежно від їі дискретності. Також виявлено необхідність передбачення ряду організаційних шляхів із запровадження платформ. Рис.: 1. Бібліогр.: 12.

Ключові слова: інформаційні системи обліку; інформаційні потоки; інформаційна платформа; управлінський облік; інформаційне забезпечення; база даних.
\end{abstract}

Скиба Ганна Іванівна - кандидат економічних наук, доцент кафедри обліку і оподаткування, Міжрегіональна академія управління персоналом (03039, м. Київ, вул. Фрометівська, 2)

E-mail: tsiluyrik@ukr.net

ORCID iD https://orcid.org/0000-0003-3751-0082

Цімошинська Оксана Валентинівна - кандидат економічних наук, заступник завідувача кафедри обліку і оподаткування, Міжрегіональна академія управління персоналом (03039, м. Київ, вул. Фрометівська, 2)

E-mail: ovmichailenko@ukr.net

ORCID iD https://orcid.org/0000-0002-2277-3317

Беженар Інна Миколаївна - кандидат економічних наук, старший науковий співробітник відділу підприємництва, кооперації та агропромислової інтеграції, Національний науковий центр «Інститут аграрної економіки» (03127, м. Київ, вул. Героїв Оборони, 10)

E-mail: inna_bezhenar@ukr.net

ORCID iD https://orcid.org/0000-0002-4584-9062

Постановка проблеми. Сучасні інформаційні системи обліку визначається досконалістю технологій, які дають можливість швидко маніпулювати інформаційними потоками для створення масштабних можливостей забезпечення організації управління підприємством.

Аналіз останніх досліджень і публікацій. На сьогодні варто відзначити вагомий внесок у розробку теоретичних і методологічних положень формування та запровадження інформаційних систем обліку провідних вітчизняних вчених, серед яких:

(ㄱ Г. І. Скиба, О. В. Цімошинська, І. М. Беженар, 2020
M. Т. Білуха [1], С. Ф. Голов [2], М. І. Козак [3], В. О. Осмятченко [4], М. П. Павлюковець [5], М. С. Пушкар [6], Н. Й. Радіонова [7], М. І. Скрипник [8], Н. М. Сіренко [9] та ін. Дослідженням теми становлення, використання та розвитку сучасних інформаційних технологій обліку займалися також науковці, М. М. Бенько, В. В. Євдокимов, В. О. Осмятченко [4], С. В. Івахненков та ін. У науковій літературі розкриваються проблеми становлення і розвитку інформаційних потоків, як ефективної системи інформаційного забезпечення прийняття рішень. Проте за сучасних умов адаптації обліку до вітчизняних правил та підходів, а разом із тим і світових економіч- 
них досягнень, потребують удосконалення теорії, методології та практики інформаційного забезпечення підприємств.

Аналіз досліджень дозволяє стверджувати, що більшість авторів при розкритті сутності категорії інформаційних систем обліку акцентують увагу на таких ключових критеріях, як наповнення; призначення та використання.

Отримані теоретичні й практичні розробки щодо формування та використання інформаційних систем обліку як основи формування інформаційного ресурсу підприємства мають вагоме значення для розвитку теорії обліку та впровадження ії положень у практичну діяльність суб'єктів господарювання.

Мета статті - визначити інформаційні системи обліку як елемент управління інформаційними ресурсами підприємства, порівняти критерії інформаційного наповнення регламентованої (фінансової) та управлінської звітності для формування інформаційного ресурсу підприємства.

Виклад основних результатів дослідження. Для того щоб технології обліку забезпечили високу ефективність управління, необхідна правильна організація формування та їх експлуатації, обробки і використання інформаційних потоків. Основними елементами оцінки інформаційних потоків слугують наступні показники: джерела виникнення, напрямок руху потоку; обсяг переданих даних, терміни забезпечення інформацією. В основі елементів інформаційних потоків необхідно відзначити їх дискретність відносно кінцевих економічних показників. Врахування дискретності даних необхідне для постановки завдань при розробці та запровадженні інформаційних систем обліку.

3 точки зору управління при оцінці використання інформаційних систем обліку важливим показником вирізняється періодичність виникнення інформаційних потоків. Регулярні потоки легше піддаються контролю та обробці, ніж нерегулярні, що мають випадковий характер. Синхронні інформаційні потоки передаються паралельно та одночасно, пов'язані з потоками іншого виду (матеріальними, фінансовими, сервісними i т. ін.). У цьому випадку отримують інформацію в режимі реального часу (on line).

Організація інформаційних потоків у режимі реального часу - найважливіша умова ефективного управління підприємством. За характером зміни даних у часі розрізняють безперервні і дискретні інформаційні потоки. Безперервний потік відображається безперервною функцією і фізично являє собою безперервно зміну значення даних (показників). За приклад може слугувати інформація про процес випуску продукції під час роботи підрозділу підприємства. Дискретний потік характеризується безкінечним рухом інформації залежно від вихідного стану потрібного показника, що пов'язаний з певним станом системи. Виходячи з фізичної сутності процесу, властивого об'єкту управління, можна виділити деякі важливі з точки зору управління різновиди неперервних i дискретних функцій, що відображають реальні інформаційні потоки.

Безперервні дані, що характеризують необхідний показник, повинні бути доступними та мати описовий характер, реальний сигнал в будь-який момент часу. При цьому не накладається ніяких обмежень на вибір моменту часу і на вибір значення самого потоку.

Безперервні дані, які характеризують змінні показники, повинні відображати інформацію у деякі фіксовані моменти часу, що визначає управлінець (кінець зміни, місяць тощо). Такі потоки даних можуть набувати будь-яких миттєвих значень, але вони визначаються лише для дискретних значень часу. Така система показників використовується при системі постачання «Just-in-time»

Змінні потоки інформації для змінних показників повинні визначатися протягом певного часу для будь-якого миттєвого значення часу.

Також слід розрізняти змінні потоки даних, які характеризують не тільки часові періоди, а й рівні управління (по підрозділах, та в цілому по підприємству).

Важливим елементом формування та використання інформаційних потоків визнана роль поділу праці, що має визначати організаційні завдання. Завдання повинні визначати зацікавлені спеціалісти, а саме: керівник підприємства, керівник проєкту, керівники підрозділів, ключові користувачі (головний бухгалтер), консультанти.

Наступним досить важливим етапом запровадження інформаційних систем обліку виступає вибір платформи, на якій проводитимуться збір, обробка та передача інформації з метою здійснення прийняття управлінських рішень. Рекомендовано практиками використання платформ, пов'язаних 3 автоматизацією бухгалтерського обліку. 
Відповідно зазначені інформаційні платформи мають характеризуватися такими можливостями:

1. Ведення управлінського обліку поряд із фінансовим та податковим обліком.

2. Надання аудиторського контролю системи, процесів та інформації.

3. Поділу прав доступу працівників до інформації.

4. Налаштування робочого плану рахунків і форм звітності (для ведення обліку за різними стандартами та по структурних підрозділах підприємства).

Враховуючи подібні можливості найчастіше використовують стандартні платформи, що пришвидшує процес запровадження та використання системи.

Після постановки цілей, вибору концепції і виконавця необхідно забезпечити виконання ряду етапів: діагностику, проєктування, розробку, впровадження, супровід і модернізацію.

На стадії проєктування керівнику підприємства бажано приділяти значну увагу постановці завдань, які має виконувати система. При цьому слід використовувати режим тестування системи, або демонстрації можливостей системи для економії часу.

Для безпосередніх користувачів системи необхідно спочатку запровадити систему на основі використання типового плану рахунків і типових нормативів ведення обліку 3 поступовим доопрацюванням іï для конкретного підприємства.
Впровадження - етап, наступний після розробки системи. На цьому етапі більшість користувачів вперше знайомляться з системою.

Впровадження відбувається за методикою, яку рекомендує виробник або консультант. Проте для будь-якого впровадження існують характерні ризики. Так, головним ризиком виступає неактуальність даних у системі.

Наступний важливий крок при впровадженні - адміністративні регламенти. Регламент складається з таких елементів: наочного опису бізнес-процесу, опису дій у відповідь користувачів у системі, наказів із використання системи.

Згаданий етап перебігає у режимі супроводження та підтримки системи. Вже на етапі впровадження від користувачів надходять заявки на доопрацювання, про помилки. Необхідно організувати підтримку в сфері нових доробок, навчання, усунення помилок, заходів, пов'язаних з оновленням версій, і т. д.

Як інформаційна система, бухгалтерський облік забезпечує інформацію в неперервному ланцюгу подвійного запису подій господарської діяльності на рахунках, а подвійний запис разом з іншими елементами методу бухгалтерського обліку створює замкнутий контур інформаційних зв'язків у системі рахунків обліку, що чітко окреслює його межі. Облік, як і будь-яка система, має свої вхідні та вихідні потоки (рис.).

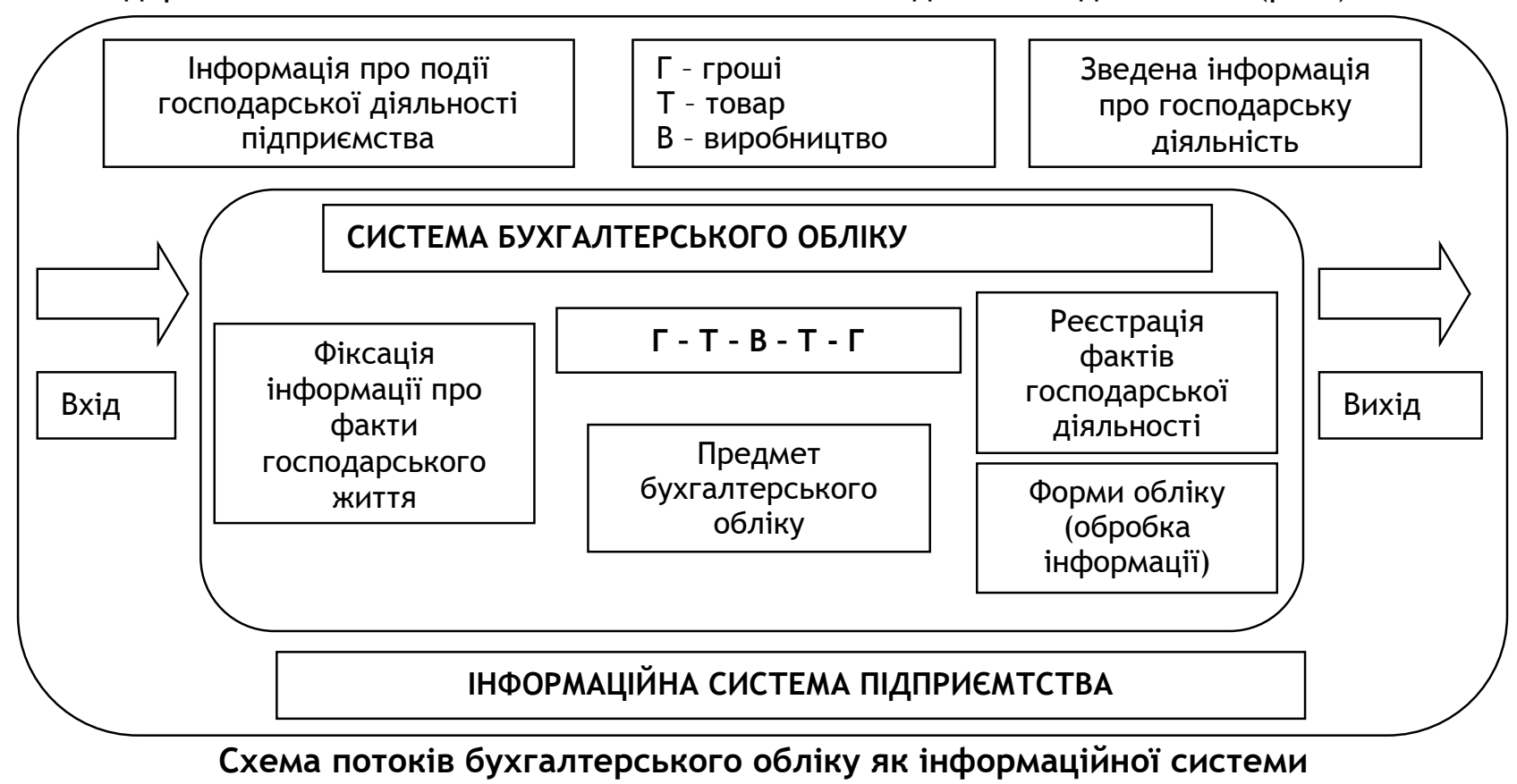

Джерело: [9]. 
Вхідним пунктом системи слугують найпростіші елементи. У бухгалтерському обліку такими елементами виступають факти господарського життя, підтверджені первинними документами. Саме вони знаходяться в основі побудови всієї системи бухгалтерського обліку. Частина даних обробляється у системі бухгалтерського обліку, в результаті чого на виході утворюється інформація, яка реалізується через фінансову звітність, податкову звітність, внутрішньогосподарську звітність. Бухгалтерський облік являє собою відкриту систему, в якій кількість елементів та зв'язків між ними змінюється залежно від входів та виходів 3 неї, яка здатна пристосовуватися до впливу оточуючого середовища [9].

Найприйнятнішим способом стає організація служби підтримки системи в межах підприємства для вирішення оперативних питань і залучення консультанта для модернізації та оновлення версій програмного за-

\section{Список бібліографічних посилань}

1. Білуха М. Т. Теорія бухгалтерського обліку : підручник. Київ : КДТЕУ, 2000. 692 с.

2. Голов С. Ф. Управлінський облік : підручник. Київ : Центр учбової літератури, 2018. 400 с.

3. Козак М. І. Автоматизація господарського обліку з використанням баз даних : автореф. дис. на здобуття наук. ступеня канд. екон. наук : спец. 08.06.04. Київ, 2005. 20 с.

4. Осмятченко В. О. Бухгалтерський облік в умовах застосування інформаційних технологій : монографія. Київ : KHEY, 2010. 263 c.

5. Павлюковець М. П. Теоретико-методологічні засади запровадження клоуд-комп'ютерної форми обліку. Облік $i$ фінанси. 2012. № 1. С. 149-151.

6. Пушкар М. С., Чумаченко М. Г. Ідеальна система обліку: концепція, архітектура, інформація : монографія. Тернопіль : Карт-бланш, 2011. 336 с.

7. Радіонова Н. Й. Методика формування збалансованої системи показників як інструмента стратегічного управлінського обліку. Стратегічні вектори соціально-економічного розвитку на мікро- та макрорівні: Всеукраїнська науковопрактична конференція (Полтава, 17-18 листопада). Полтава, 2016. С. $175-178$

8. Скрипник М. І. Організація обліку витрат у розрізі центрів витрат та центрів відповідальності. Облік і фінанси АПК. 2011. № 1. C. 46-49. URL : http://magazine.faaf.org.ua/ organizaciya-obliku-vitrat-u-rozrizi-centriv-vitrat-ta-centrivvidpovidalnosti.html.

9. Сіренко Н. М., Баришевська І. В., Щербина Ю. О. Бухгалтерський облік в управлінні підприємством : курс лекцій. Миколаїв : МНАУ, 2016. 132 с.

10. Cloud Computing Group Who invented the term Cloud Computing? URL : http://blogs.idc.com/ie/?p=543.

11. Eric Schmidt, Web 2.0 vs. Web 3.0. URL : http: / /www.youtube.com/watch?v=T0QJmmdw3b0.

12. Joseph M. Hellerstein, Surajit Chaudhuri, Mendel Rosenblum: Proceedings of the 1st ACM Symposium on Cloud Computing, SoCC 2010, Indianapolis, Indiana, USA, June 10-11, 2010. безпечення, а також для проведення індивідуального навчання.

Висновки. Обґрунтовано визначення інформаційних систем обліку як елемента управління ресурсами підприємства для формування саме інформаційного ресурсу суб'єкта господарювання, проведено порівняння критеріїв наповнення регламентованої (фінансової) та управлінської звітності. Для запровадження інформаційних систем обліку в підприємстві необхідно передбачити ряд методичних заходів щодо поділу інформації залежно від ії дискретності. Також передбачити ряд організаційних шляхів із запровадження платформ, зокрема це власне вибір платформи, вибір працівників підприємства, які мають відповідати за ії впровадження. Важливим елементом вирізняється підтримка системи в актуальному стані та навчання персоналу, що працює із системою.

\section{References}

1. Bilukha, M.T. (2000). Teoriia bukhhalterskoho obliku: pidruchnyk [Accounting theory: textbook]. Kyiv: KDTEU [In Ukrainian].

2. Holov, S.F. (2018). Upravlinskyi oblik: pidruchnyk [Management accounting: a textbook]. Kyiv: Tsentr uchbovoi literatury [In Ukrainian].

3. Kozak, M.I. (2005). Avtomatyzatsiia hospodarskoho obliku $\mathrm{z}$ vykorystanniam bakh danykh [Automation of business accounting using databases]. Candidate's thesis. Kyiv [In Ukrainian].

4. Osmiatchenko, V.O. (2010). Bukhhalterskyi oblik v umovakh zastosuvannia informatsinykh tekhnolohii: monohrafiia [Accounting in the context of information technology application: monograph]. Kyiv: KNEU [In Ukrainian]

5. Pavliukovets, M.P. (2012). Teoretyko-metodolohichni zasady zaprovadzhennia kloud-komp'iuternoi formy obliku [Theoretical and methodological principles of introduction of cloud-computer form of accounting]. Oblik $i$ finansy, 1, pp. 149-151 [In Ukrainian].

6. Pushkar, M.S. \& Chumachenko, M.H. (2011). Idealna systema obliku: kontseptsiia, arkhitektura, informatsiia: monohrafiia [The ideal accounting system: concept, architecture, information: monograph]. Ternopil: Kart-blansh [In Ukrainian].

7. Radionova, N.Y. (2016). Metodyka formuvannia zbalansovanoi systemy pokaznykiv yak instrumenta stratehichnoho upravlinskoho obliku [Methods of forming a balanced system of indicators as a tool of strategic management accounting]. Stratehichni vektory sotsialnoekonomichnoho rozvytku na mikro- ta makrorivni: Vseukrainska naukovo-praktychna konferentsiia. (pp. 175-178). Poltava [In Ukrainian].

8. Skrypnyk, M.I. (2011). Orhanizatsiia obliku vytrat u rozrizi tsentriv vytrat ta tsentriv vidpovidalnosti [Organization of cost accounting in terms of cost centers and responsibility centers]. Oblik $i$ finansy APK, 1 , pp. 46-49. Retrieved from: http: / /magazine.faaf.org.ua/organizaciya-obliku-vitrat-u-rozrizicentriv-vitrat-ta-centriv-vidpovidalnosti.html [In Ukrainian].

9. Sirenko, N.M., Baryshevska, I.V. \& Shcherbyna, Yu.O. (2016). Bukhhalterskyi oblik v upravlinni pidpryiemstvom: kurs lektsii [Accounting in enterprise management: lectures]. Mykolaiv: MNAU [In Ukrainian]. 


\section{Skyba H. I., Tsimoshynska O. V., Bezhenar I. M. Implementation of information accounting systems}

The purpose of the article is to define accounting information systems as an element of enterprise information resource management, compare the criteria for the content of regulated (financial) and management reporting for the formation of an enterprise information resource.

Research methods. General and special methods of scientific knowledge were used: system approach and system analysis (in determining the essence and basic elements of the assessment of information flows); historical and logical method (in the study of the formation, development and development of theoretical and methodological provisions for the formation and implementation of information accounting systems); analysis and synthesis (when developing proposals for the implementation of accounting information systems in the practical activities of the enterprise); monographic (when assessing the results of adaptation of employees of the enterprise, who should be responsible for the implementation of the platform).

Research results. The great importance of the obtained theoretical and practical developments on the formation and use of information accounting systems as the basis for the formation of an enterprise information resource for the development of accounting theory and the introduction of its provisions into the practical activities of business entities has been proved. A number of practical situations that may accompany the implementation of information accounting systems for information support of effective management are stated.

Scientific novelty. Review of the possibility of choosing an information platform on which the collection, processing and transmission of information will be carried out in order to make management decisions.

Practical significance. The necessity of introducing accounting information systems at the enterprise is substantiated with the prediction of a number of methodological measures for the division of information, depending on its discreteness. It also identified the need to foresee a number of organizational paths for the implementation of platforms. Figs.: 1. Refs.: 12.

Keywords: accounting information systems; information flows; information platform; management accounting; information support; database.

Skyba Hanna Ivanivna - candidate of economic sciences, associate professor (docent) of the department of accounting and taxation, Interregional Academy of Personnel Management (2, Frometivska St., Kyiv, 03039)

E-mail: tsiluyrik@ukr.net

ORCID iD https://orcid.org/0000-0003-3751-0082

Tsimoshynska Oksana Valentynivna - candidate of economic sciences, deputy head of the department of accounting and taxation, Interregional Academy of Personnel Management (2, Frometivska St., Kyiv, 03039)

E-mail: ovmichailenko@ukr.net

ORCID iD https://orcid.org/0000-0002-2277-3317

Bezhenar Inna Mykolaivna - candidate of economic sciences, senior research fellow of the department of entrepreneurship, cooperation and agro-industrial integration, National Scientific Centre "Institute of Agrarian Economics" (10, Heroiv Oborony St., Kyiv, 03127)

E-mail: Inna_Bezhenar@ukr.net

ORCID iD https://orcid.org/0000-0002-4584-9062

\section{Скиба А. И., Цимошинская О. В., Беженар И. Н. Внедрение информационных систем учёта}

Цель статьи - определить информационные системы учёта как элемент управления информационными ресурсами предприятия, сравнить критерии информационного наполнения регламентированной (финансовой) и управленческой отчетности для формирования информационного ресурса предприятия.

Методика исследования. Использованы общие и специальные методы научного познания: системный подход и системный анализ (при определении сущности и основных элементов оценки информационных потоков); историкологический метод (при исследовании становления, развития и разработки теоретических и методологических положений формирования и внедрения информационных систем учёта); анализа и синтеза (при разработке предложений по внедрению информационных систем учета в практической деятельности предприятия); монографический (при оценивании результатов адаптации работников предприятия, которые должны отвечать за внедрение платформы).

Результаты исследования. Доказано весомое значение полученных теоретических и практических разработок по формированию и использованию информационных систем учёта как основы формирования информационного ресурса предприятия для развития теории учёта и внедрение ее положений в практическую деятельность субъектов хозяйствования. Изложены ряд практических ситуаций, которые могут сопровождать внедрение информационных систем учета для информационного обеспечения эффективного управления.

Элементы научной новизны. Обобщены возможности выбора информационной платформы, на которой будут проводиться сбор, обработка и передача информации с целью осуществления принятия управленческих решений.

Практическая значимость. Обоснована необходмость введения информационных систем учёта на предприятии с предсказанием ряда методических мероприятий по разделу информации в зависимости от ее дискретности. Также выявлена необходимость предвидения ряда организационных путей по внедрению платформ. Илл.: 1. Библиогр.: 12.

Ключевые слова: информационные системы учёта; информационные потоки; информационная платформа; управленческий учёт; информационное обеспечение; база данных. 
Скиба Анна Ивановна - кандидат экономических наук, доцент кафедры учёта и налогообложения, Межрегиональная академия управления персоналом (03039, г. Киев, ул. Фрометовская, 2)

E-mail: tsiluyrik@ukr.net

ORCID iD https://orcid.org/0000-0003-3751-0082

Цимошинская Оксана Валентиновна - кандидат экономических наук, заместитель заведующего кафедрой учёта и налогообложения, Межрегиональная академия управления персоналом (03039, г. Киев, ул. Фрометовская, 2)

E-mail: ovmichailenko@ukr.net

ORCID iD https://orcid.org/0000-0002-2277-3317

Беженар Инна Николаевна - кандидат экономических наук, старший научный сотрудник отдела предпринимательства, кооперации и агропромышленной интеграции, Национальный научный центр «Институт аграрной экономики» (03127, г. Киев, ул. Героев Обороны, 10)

E-mail: inna_bezhenar@ukr.net

ORCID iD https://orcid.org/0000-0002-4584-9062

Стаття надійшла до редакції 20.10.2020 р.

Фахове рецензування: 02.11.2020 р.

Бібліографічний опис для цитування:

Скиба Г. І., Цімошинська О. В., Беженар І. М. Впровадження інформаційних систем обліку. Економіка АПК. 2020. № 11. С. 74 - 79. https://doi.org/10.32317/2221-1055.202011074

Skyba, H.I., Tsimoshynska, O.V. \& Bezhenar, I.M. (2020). Vprovadzhennia informatsiinykh system obliku [Implementation of information accounting systems]. Ekonomika APK, 11, pp. 74 - 79 [In Ukrainian]. https: / / doi.org/10.32317/2221-1055.202011074

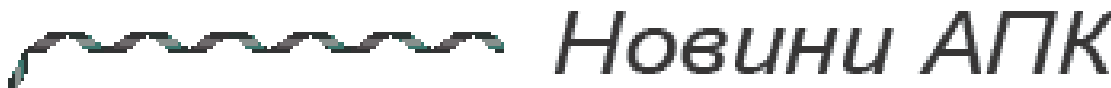 \\ Продукція тваринного походження не в змозі компенсувати втрати зернових - коментар Юрія Лупенка сайту AgroPolit.com}

Виробництво сільськогосподарської продукції в Україні знижується: за період із січня по серпень 2020 року воно скоротилося на 9,9\%, у порівнянні з аналогічним періодом минулого року. Фахівці пояснюють спад, в першу чергу, кліматичними змінами.

«Цього року на ситуацію досить сильно вплинули природні умови, вони були набагато гірші за торішні. Власне, це й стало першопричиною зменшення виробництва зернових у першій половині 2020 року. Також варто зважати на той факт, що продукція тваринного походження не в змозі компенсувати втрати зернових. Тут варто згадати і про зменшення поголів'я великої рогатої худоби та збільшення імпорту молочної продукції. Тож за таких умов у другій половині 2020 року навряд чи можна очікувати позитивної динаміки у виробництві: втрат від кліматичних факторів вже не зміниш, як і посівних площ та відповідних культур. Єдине, що може допомогти у цій ситуації - це мінімізація втрат під час збору того врожаю, який виріс. Крім того, минулий рік був рекордним за показниками врожайності, а рекордні показники завжди важче утримувати, ніж навіть досягати», прокоментував для AgroPolit.com ситуацію директор Національного наукового центру «Інститут аграрної економіки» академік НААН Юрій Лупенко.

За його словами, такий спад не можна назвати критичним, хоча більшість ключових показників пов'язані з обсягом зернових, а це основний продукт аграрного виробництва й експорту.

«Однак порівнювати досягнення чи провали АПК краще за річними показниками, а не за перші 6 місяців, адже залежно від тих самих погодних умов в різні роки по різному починаються збори врожаю, що впливає на проміжні показники. Більш-менш точні розрахунки продемонструють дані за рік або хоча б за перші 9 місяців, однак тенденції можна визначити, і вони, швидше за все, залишаться незмінними. А це означає, що спаду виробництва продукції АПК негативно позначиться на економічних показниках країни, зокрема на експорті та ВВП», - зазначив Юрій Лупенко. 